\title{
A Literacy Exercise: An Extracurricular Reading Program as an Intervention to Enrich Student Reading Habits in Qatar
}

\author{
Ramzi Nasser \\ College of Education, Qatar University \\ PO Box 2713, Doha Qatar \\ Tel: +97466057952 E-mail: ramzin@qu.ed.qa
}

Received: 17-05- 2013

Accepted: 27-06- 2013

Published: 01-07- 2013

doi:10.7575/aiac.ijels.v.1n.1p.61

URL: http://dx.doi.org/10.7575/aiac.ijels.v.1n.1p.61

\begin{abstract}
This paper evaluates an extracurricular reading activity in Qatari schools. The paper presents a two-month extracurricular reading program designed for fourth grade students. The methodology used triangulation of the data to analyze, in detail, the students' primary perceptions towards reading, teacher self-efficacy, teacher instructional behavior and home literacy measures. The program was implemented in four randomly selected schools. The reading program was announced to each school, and students in the four schools were asked whether they wished to enroll contingent upon receiving parental consent. There were 248 students in the treatment group (students enrolled in the English and Arabic reading program), and 176 students were recruited for the control group (not enrolled in the reading program). The main design was a randomized subjects pretest-posttest control group design and analytical split-plot analysis of variance (ANOVA) design. The findings of this study suggested that students in the reading program demonstrated greater interest in reading than those who did not enroll in the reading program, even when factoring out the effects of parents and home environments. The extracurricular program was significant to the extent that it has improved students' reading habits. An increase in breadth and depth of such programs shall increase language literacy and numeracy in schools and can improve the school culture towards a more student-teacher interactions and engaging activities.
\end{abstract}

Keywords: Reading, extracurricular activity, reading week, reading for pleasure, teacher effectiveness, reading attitudes, Qatar

\section{Introduction}

Children's ability to read is of central concern to both society and schools, particularly as reading has been associated with having a general positive effect on children's academic learning, progress and overall performance (Gorman, 1987). There is a general consensus among experts that a child who voluntarily reads is likely to become a proficient and intensive reader later in life.

There are very few studies that explore what reading for pleasure might look like and what the impact of such programs might be on promoting reading in authentic contexts. Reading in such context supports the critical connection between written texts and the community, encouraging interactions with books among school students, teachers and other related stakeholders, including parents and the wider community. Underlying the social nature of reading, children who have more opportunities to engage in literacy-related social activities in and outside of the home have more positive views about reading, engage in more leisure reading, demonstrate greater reading achievement (Whitehurst \& Lonigan, 2001) and, subsequently, demonstrate greater academic achievement.

The premise behind literacy-related activities is to improve literacy skills and thereby improve reading and writing fluency among children. Persuasive reading is a strategic target for many organizations in Qatar because, in a knowledge-based economy, it is considered a basic survival skill, especially for individuals who, in the early grades, experience difficulties developing literacy skills and therefore continue to struggle in school and in life. For instance, McCardle and Chhabra (2004) found the following consequences due to reading failure in the United States. a) By middle school, children who read well can read at least 10,000,000 words during the school year, and children who struggle with reading read only 100,000 words during the school year (one percent of what good readers can read). b) Of the 10 to $15 \%$ of students who drop out of high school, approximately $75 \%$ of them have reading problems. c) At least half of the young adults with criminal records have reading difficulties. And lastly, d) predicting fourth grade reading failure rates. To the extent that half of the children and adolescents with a history of substance abuse have reading problems.

The importance of a good beginning instruction in literacy skills suggests that language knowledge should include such things as alphabetic principles. For instance, at the end of first grade, there is a 0.88 probability that children will be good readers in grade four, but those who are poor in alphabetic principles had a 0.87 probability of being poor readers in grade four (Juel, 1988). In addition, studies have shown that improving phonological awareness improves literacy 
skills in different languages (Ball \& Blachman, 1991; Abu-Rabia \& Taha, 2006). Furthermore, such phonological awareness is often driven by such things as fluency in reading and more time spent on reading.

Additionally, according to Cummins (1979), that knowledge in one's first language transfers to a second language, so do the problems in literacy-related skills in one's first language impede the development of literacy in a second language. More recently, Figueredo (2006) and Seymour (2006) argued that the orthography of first and second languages may also affect the development of literacy skills, especially with respect to spelling skills. Although very few studies have been conducted on the transfer of Arabic as an L1 to English as an L2, there is sufficient support to show the phonological, morphological, and orthographic characteristics of the L1 will transfer to the L2. In one of the first studies, Durgunoglu, Nagy and Hancin-Bhatt (1993) found that the knowledge of phonological awareness in Spanish as an L1 had a facilitating effect on phonological awareness of English as an L2. Bilingual children take advantage of their metalinguistic knowledge in their L1 to master literacy skills in an L2. It should, however, be noted that all skills, such as phonological awareness, alphabetic principle, fluency, vocabulary, and comprehension, do not develop at the same rate, and mastery in one skill may contribute to the faster development of another skill.

Reading has also been considered as multidimensional and has been recognized as a socially engaging exercise. Research has shown that readers experience a clear and mutually reinforcing relationship between friendship and reading. Some friendship roles include parents, friends and peers, as they generally play a significant role in early adolescence with regard to academic adjustment and achievement (Ryan, 2011). The most impactful social reading exists for those who read in pairs and those who join in reading activities with close family members, i.e., parents who read with the child and switch from reading together to reading alone, providing the child the right support to develop reading skills (Murad \& Topping, 2000; Topping, 2000). Such techniques seem to be most successful among second language learners (Murad \& Topping, 2000). The importance of the environmental (i.e., instructional) experiences associated with literacy is strongly emphasized with respect to language competence among children (Connor, Piasta, Fishman, Glasney, Schatschneider, Crowe, Underwood, \& Morrison, 2009). Thus, reading should exist in a "virtuous circle" in which friends encourage reading for pleasure and shared reading experiences solidify friendships and further reading (Howard, 2008, p.109).

Individual leisure reading provides deep personal gratification, such as escapism, relaxation, self-discovery and selfempowerment (Birkerts, 1994). Based on this premise, we wanted to incorporate reading activities into and through the concept of leisure. We proposed promoting literacy through an extracurricular reading program that is based on the principles of literacy value inculcated into the traditional curriculum. The implementation of the reading program was through an extracurricular after-school program-activity. These types of programs require regular participation, where non-familial adults guide students in socially immersed environments designed to build skills in leisure activities and meaningful tasks (Fredricks \& Eccles, 2005). Research has shown that student participation in such activities is associated with higher academic achievement, and there is evidence of a positive association with time spent in extracurricular activities and other areas of academic success, such as school completion and post-secondary achievement (Mahoney, Harris, \& Eccles, 2006) and motivation (Fredricks \& Eccles, 2006). Some studies with longer duration (2 to 3-years) of participation generally associated after-school activities with more positive outcomes (Granger \& Kane, 2008), while other studies have emphasized the differences between depth and breadth of afterschool activities. While depth suggests a single activity with increased intensity in that activity, breadth includes a number of activities in which students engage, but without the depth provided when participating in a single activity. Fredricks and Eccles (2010) suggested that there are several reasons why breadth of activities may be beneficial for youth development. For example, by providing a breadth of activities, students are introduced to a variety of experience, thus allowing children to explore and find their own interests and competencies by indulging in a number of different experiences. On the other hand, others have argued that investing time and energy in one context is necessary for developing expertise in a single domain (Ericsson, 1996). We merged both of these ideas with the belief that breadth and depth provides the best of the two. Hence, in one context - "reading for pleasure" — we build-in a number of activities, such as art, writing, theatre, film, home economics, reading and discussion.

It is generally accepted in academia that reading is not a "natural thing" but an academic subject that students acquire through direct instruction (Gough \& Hillinger, 1980). Furthermore, it takes a very long time for students to learn to read (Treiman, 2000), and requires deliberate instruction for the learner to acquire the component skills involved in reading (Rayner, Foorman, Perfetti, Pesetsky, \& Seidenberg, 2001). Most children require intensive reading instruction to achieve a high degree of literacy. Teachers develop the ability to know how much time they need to spend teaching reading skills and content (Gibson \& Dembo, 1984) to ultimately improve student learning, and thereby improve student outcomes (Ashton \& Webb, 1986; Guskey \& Passaro, 1994). Teachers build this sense of efficacy in their teaching through experience and continuous professional development. According to Bandura (1986), self-efficacy allows for "people's judgments of their capabilities to organize and execute courses of action required to attain the designated types of performances." While this sense of efficacy is related to teacher quality, it eventually translates into student performance.

This study attempts to understand the impact of an extracurricular program through a formative evaluation of the teacher self-efficacy and through observation of the reading program related to teacher instructional behaviors. The assessment allowed us to also validate the reading program. This paper and study describes an extracurricular reading program. The research part of this study aims to evaluate an extracurricular reading program addressing the quality of teacher self-efficacy as well as instructional behaviors through a self-efficacy instrument and direct observations by the 
researchers. The study also intends to measure students' reading attitudes/habits, and contribute to an ongoing body of research on after-school programs that focuse on comparing students' perceptions of these programs (Durlak \& Weissberg, 2007). The main hypothesis is that fourth grade students who enroll in the extracurricular reading program will have increased positive reading attitudes and improved reading habits compared to those who did not enroll in the program.

\subsection{An extracurricular program in Qatar}

Both staff from the Childhood Cultural Center and Qatar University faculty established the reading week program during the 2009/2010 school year. The following school year, 2010/2011, researchers from both organizations applied for a grant supported by the National Qatar Research Fund and a fully developed program was implemented in the academic year 2011/2012. Based on the research literature, the reading program ran for two month as an activity in which all primary grade school children were invited to participate. The reading program promoted practices recommended by the International Reading Association, and it was based on the Curriculum Standards of the Supreme Education Council (I.e., Ministry of Education). Furthermore, the reading program highlighted the importance of activebased reading, a concept where reading is integrated with imaginative and creative practices.

The reading program was a supplemental after-school activity that integrated reading interventions with art, writing, theatre, film, home economics, reading and discussions. The reading program used one fiction book called Hamda and Fasaikra. The book was an age-appropriate book and was chosen because it was set in the Middle East and presented moral and "culturally appropriate" content with respect to the context of Qatari society. Furthermore, it was one of the few books directed towards young children, which was available in both English and Arabic. The reading program involved the following activities:

Activity 1

Reading Activity- Reading aloud: students read aloud to become acquainted with word sounds. Teachers used special sounds for each character.

Teachers read the story individually and with students and underlined sounds for various words and characters.

\section{Activity 2}

Reading Activity- Reading aloud: the whole class discussed the different characters in the story. Question and answer session. Questions asked for the study included the following:

1. Who were the main characters?

2. Who is the hero of the story?

3. How many people are in the story? How many animals?

The question and answer session continued, and teachers guided the discussion.

Activity 3

The story was broken into parts, and specific events were recreated by the students. The students also developed mind maps of these events, inferred relationships between characters, and envisioned/predicted future events. The students also narrated these events to other fellow students.

The students presented their concept maps and discussed the events with peers. The students posted their concept maps on large poster paper in class for others to see.

Activity 4

The students read parts of the story, built activities around the events as in play, and performed or demonstrated specific events. The students were asked to recreate a scene and integrate a character from the story into an old Qatari traditional event or story and then give a 5 minute presentation to the class. The students were given the option to develop a setting from various artifacts and then act as tour guides for other events. The students acted out and took leadership roles as "cultural attaches."

Activity 5

The students were asked to imagine they were part of an event. They then described what they imagined to their classmates.

Activity 6

The students, with teacher guidance, conducted a library search on traditional Qatari food. Students would also participate in a cooking session in the school kitchen. Students were asked to imagine that a feast is taking place around the context of the story. The students narrated the events of the feast based on the context of the story line.

Activity 7

Reading together activity- The students continued reading in groups. The students were asked to discuss a specific event or character.

Activity 8

The students designed a re-enactment/play of a specific part in the story or the whole story. The students designed cultural artifacts as well as clothing. They practiced the narration of the play.

Activity 9

The students wrote letters to the main characters of the story. The students shared the letters by sending them to each other and reading aloud how each student wanted the story ends.

Activity 10 
Culmination Activity: The teachers and students from participating schools produced a play, a short movie of the story, and presented it in a final ceremony where all the schools attended. All the participating students and teachers received certificates of recognition.

Each of the activities was mapped to the Qatar National Curriculum Standards for Arabic as well as English to make the activities more relevant to the Qatari educational context and more purposefully sound for the teachers and school leaders.

\section{Methodology}

The general methodology of this study applies a convergent method, or triangulation method, in which multiple methods of data collection and analysis were used (Ary, Jacobs \& Razavieh, 2002). This method is strengthened by the various measures from different sources (Merriam, 1988) to determine the conclusion of the effectiveness of the reading program and whether the program has improved students' reading habits. Four measures were used, a classroom walkthrough observation, a self-efficacy measure, a student reading/attitude questionnaire, and a home literacy questionnaire.

\subsection{Implementation of the After-school Reading Program}

There were four schools selected for the study. Two of these schools were selected randomly from all male primary schools (grades 1-6), and two were selected from female schools. Once the schools were selected, the Childhood Cultural Center approached the leadership of the schools and informed them through a letter of intent about the reading program. All of the schools selected agreed to be part of the study. The Childhood Cultural Center asked two teachers from each school to volunteer for the reading program, one English teacher, and one Arabic teacher from each school. Thus, we had eight teachers involved in the reading program. The schools were segregated according to gender. The program was run in each school in two separate classes, one in an Arabic class, and the second in an English language class. The students who did not enroll in the program were in classes considered as the control group.

Each reading group had no more than 25 students. All facilitators of the reading program were teachers of the English or the Arabic language classes who volunteered to be part of the program. Each teacher met for an hour to discuss the extracurricular reading program that they were to direct as an extracurricular activity. The students attended the afterschool activity twice a week. The facilitators, i.e., school teachers, were trained prior to the start of the program via a three-day professional development program, during which they simulated the class activities. The extracurricular program was conducted in both English and Arabic over a two-month period.

\subsection{Ethical Compliance}

Signed consent forms were required from all participating student parents', given approval for their children to participate in the reading program. A request was made at each of the four participating schools for English and Arabic teachers who would be interested in volunteering to implement the program at their respective schools. Two teachers from each school volunteered. The reading program was run in the resource room of the school.

The parents of school children were also sent and asked to complete the home literacy questionnaire. They were also sent a consent form giving their approval for their children to respond to the questionnaires.

The reading program ran for eight weeks and met twice a week. The reading attitude questionnaire was administered to students before and after the reading program. A teacher self-efficacy assessment was administered before and after the teachers attended a training seminar on the above mentioned activities. While the classroom observation measure was administered before, during and after the reading program and was based on three observations (every two weeks).

\subsection{Study Sample}

As schools are segregated according to gender, these schools were selected randomly and were first stratified according to the gender of the school. We asked the school administration to select two fourth grade classes to participate in the reading program. In each of the four schools, one class was conducted in Arabic, and the second class was in English. Accordingly, there were four classes to which the reading program was administered in Arabic and four classes to which the reading program was administered in English.

\subsubsection{Teacher Sample}

Eight teachers administered the reading program. The teachers were voluntarily recruited to the study and compensated for their work. Thus, for each school, there were two teachers, one who administered the facilitated the reading program in Arabic, and one who administered it in English. All teachers held bachelor's degrees in Arabic or English. All teachers were female as, by law, only female teachers are permitted to teach in primary independent schools in Qatar.

\subsubsection{Student Sample}

The sample was made up of fourth grade students. There were 176 students who were in the control group, and 248 were in the treatment group (those students who enrolled in the reading program in either English or Arabic). There were 180 males and 244 females in the study. The age range of the students was between 9 and 12 years.

\subsection{Instruments}

Four basic instruments were used for the study. The four instruments included the teacher self-efficacy measure, the reading attitude questionnaire, the classroom walkthrough observation and the home literacy questionnaire. 


\subsubsection{Classroom Observation}

Teacher observations were conducted using the Classroom Observation Measure (COM) (Ross \& Smith, 1996 cited in Ross, Troutman, Horgan, Maxwell, Laitinen, \& Lowther, 1997), which measures the extent to which certain effective instructional strategies are demonstrated during a class period. The COM has been used in a number of studies and has been found to be reliable and valid (Ross, Smith, Lohr \& McNelis, 1994; Ross, Troutman, Horgan, Maxwell, Laitinen \& Lowther, 1997). A critical component of the COM is that it provides the observer with an opportunity to record field notes - a factor similar to other recent teacher observation instruments incorporating both qualitative and quantitative data (Knight \& Smith, 2004; Waxman, Hilberg, \& Tharp, 2004). The main items that the researchers were interested in was teacher instructional items that included items such as teacher-facilitated engagement, activities related to one another and to previous learning, connected ideas, initiated experiences, project-based activities, discussion, experiences, coaching, feedback, monitoring student thinking, related concepts, variety of modalities, cross-disciplinary encouragement, warmth, motivation, extended conversations, expanded student vocabulary, exposure to fluent reading, and exposure to word knowledge. The items were rated on a rating scale from a low of "1" to a high of "3". The " 2 " being the mid-rating point. The items were summed and divided by the number of the items, recoding any negative items. The items of the COM is shown in Appendix B.

\subsubsection{Teacher Self-Efficacy Measure}

The individual teacher's personal beliefs about her ability to successfully carry out a particular activity or task play an important role in influencing individual achievement (Bandura, 1986). Instructional practices of teachers who have a strong sense of self-efficacy have been shown to produce positive student outcomes. An adaptation of the teacher selfefficacy (TSE; Tschannen-Moran \& Woolfolk Hoy, 2001) measure was used to assess teacher self-efficacy in the present study. The purpose was to determine whether self-efficacy contributed to the quality of the reading program.

The TSE is a 19-item measure that rates items on a 5-point scale ranging from 1 (not confident at all) to 5 (a great deal of confidence). Three main dimensions constitute the TSE. The first is the ability of teachers to find resources, ask colleagues, and judge the quality of the material and the teaching (ability to find resources and judge quality). The second is the ability to develop the reading program, and the third is the ability of teachers to motivate students to read (ability to motivate students). In general, the self-efficacy items describe teaching-related tasks (e.g., "How much do you do to craft good questions for students?"), with four items in each of three domains (instructional strategies, student engagement, and classroom management; see Appendix A).

\subsubsection{The Reading/Attitude Questionnaire}

It is generally believed that a child who reads voluntarily is likely to have a positive attitude towards reading and is likely to become a proficient and intensive reader at an early age. To investigate this premise, a reading questionnaire was developed. The questionnaire was adapted from Davies \& Brember (1995) and is presented in Appendix C. The reading attitude questionnaire asked about students' reading attitudes and included items such as "do you like reading?", "how do you feel when you read to your teacher or peer?", "how do you feel when you read to yourself?", "I always like reading?", "what is your feeling when you are reading?" and "how do you feel when you are reading by yourself at home?" The response format of the questions was in the form of happy faces as well as a rating scale. Accordingly, if the fourth grade student agreed with the statement, the student selected a "happy face," which indicates that the student has a positive attitude toward reading. The reading questionnaire was administered prior to the reading program and again at the end.

\subsubsection{Home Literacy Practices: A Home Literacy Questionnaire}

The fourth questionnaire was developed to understand the impact of the parents' influence on reading practices. The questionnaire elicited information as to whether parents were engaged in their children's activities. Questions in the instrument asked whether parents encouraged their students in their reading activities, created the right environment for reading, and provided the necessary resources for reading. The results of these findings were used to factor out and control for the effects of parents' influence on students who had participated in the reading program. Table 1 presents the questions from the home literacy questionnaire. The questions were reformatted for a rating scale, and parents rated the responses from "Very often=5," "Often=4," "Sometimes=3," "Seldom=2" and "Never=1."

\subsection{Procedure}

Teachers that facilitated the extracurricular reading program went through a professional development that helped them to prepare activities for the reading program. The TSE was administered to teachers prior to the their reading program professional development, then after the end of the 8-week extracurricular reading program, the TSE was administered again. The extracurricular activity was observed over three periods. Two student groups were formed for the study. Those students who did not enroll in the reading program were considered the control group. Students who enrolled in the reading program were randomly assigned to the extracurricular reading program and considered as the experimental group. Both control and experimental groups were given the reading attitude questionnaire pre and post program. Parents in the $7^{\text {th }}$ week of the reading program were given the home literacy questionnaire.

\subsection{Analysis}

A Cronbach's alpha analysis was performed for each of the items on the teacher self-efficacy measure, reading attitude questionnaire and home literacy questionnaire. A mean score was calculated for the home literacy questionnaire items and used to describe the ratings on each of the items. The TSE was administered prior to the training of teachers and 
after the teachers attended a professional development. A t-test was performed for each of the TSE dimensions. Prior to the main analysis, we ran an ANOVA to determine differences between observers on the COM. We also measured students' reading habits (attitudes) prior to enrollment into the reading program and post and ran an ANOVA comparing means pre and post reading attitudes. In addition, we ran an analysis of covariance using home literacy as the covariate to weave out parental influence. The main analysis was conducted using a split-plot analysis of variance (ANOVA) to determine whether there were any changes in the treatment group or control group pre- and post-reading program.

Table 1. Home literacy questionnaire

1. I read to/with my child.

2. My child and I sing/used to sing songs together

3. I play language games with my child when we are in the car, or during other waiting times.

4. I encourage my child to practice writing at home, through notes and journals and electronic communication.

5. My child checks out books from the library.

6. My child and I discuss writing in the environment around us (such as restaurant menus and advertising signs).

7. I ask my child questions about what we read together.

8. When I read to my child, I vary my voice and tone, to show expression.

9. I encourage my children to ask questions about things that we read together.

10. My child and I go to bookstores and buy books for him or her.

11. Newspapers, magazines and other reading materials can be found in our house.

12. Our child uses computer programs to aid in their language learning.

13. My child watches educational programs on TV.

14. How often does the child's family members read for pleasure?

15 . How often does your child read for pleasure independently?

16. I tell oral stories to my child.

17. How do you choose the books that your child reads?

18. Approximately how many adult books are there in your home?

19. Approximately how many children's books are there in your home?

\section{Findings}

The first main analysis included a reliability analysis of the eight items from the reading attitude questionnaire and the self-efficacy questionnaire made through a Cronbach's alpha analysis. With respect to the reading attitude questionnaire, we used the pre-program instrument to obtain the Cronbach's alpha, which was 0.80. The second analysis reported the Cronbach's alpha for the teacher responses on the TSE to be 0.70 . The final reliability analysis assessed the reliability of the home literacy questionnaire. The Cronbach's alpha reached 0.89 level. Finally to assess inter-rater reliability of the observation made through the COM we ran an ANOVA, a non-significant $\mathrm{F}(2,75)=0.14$, $\mathrm{p}=0.87$. suggesting the acceptance of the null hypothesis that no difference occurs between the different raters.
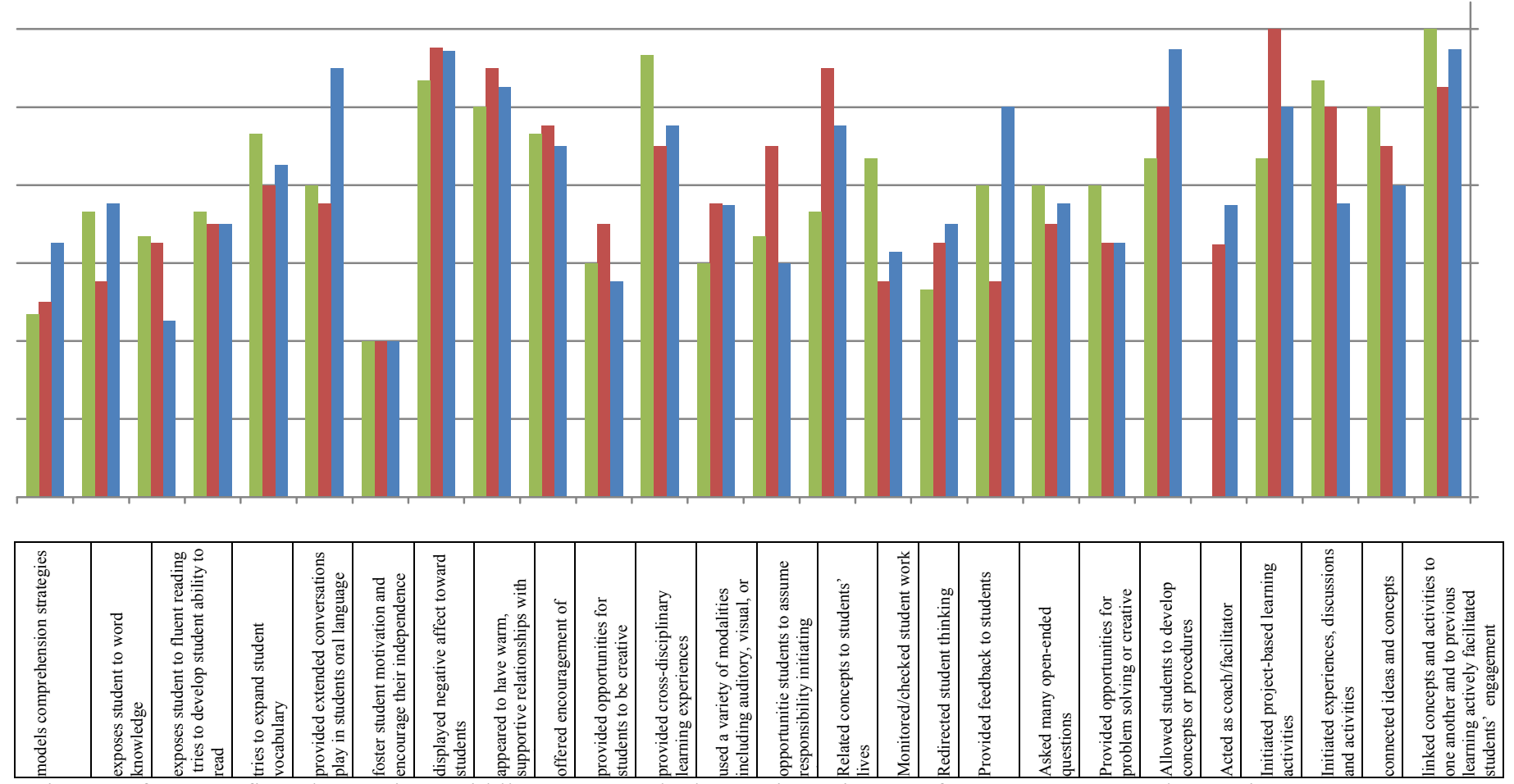

First Bar from top first observation, Middle Bar Second Observation, First Bar from Bottom Last Observation

Figure 1. Bar graphs representing the means of the Classroom Observation Measure clauses 
The second analysis included the Classroom Observation Measure (COM) (Ross \& Smith, 1996) checklist. The observations reflected what the teachers did in the reading program such as creating learning activities, enhancing language acquisition and engaging in reading activities. The results showed that the teachers built supportive relationships, provided encouragement, promoted creativity, monitored student work, created auditory and visual experiences, acted as facilitators, initiated experiences, engaged in discussions, connected ideas and concepts, and engaged students in various activities. On the other hand, teachers contributed little to children's language acquisition skills, comprehension strategies, word knowledge, vocabulary or the teaching of project-based or cross-disciplinary work (Figure 1 presents the results of the COM).

In the third analysis, we analyzed the TSE data. The purpose of this analysis was to determine whether teachers had a strong sense of self-efficacy in relation to strategizing for the course, developing the course and motivating students. The eight teachers took the self-efficacy questionnaire pre- and post-professional development program. The differences are reported in Table 2 for each of the dimensions. While no significant difference found between the preand post-training period, the means were higher in the post-training than in the pre-training period. In addition, teachers exhibited higher means than the median scores for the three dimensions at the pre- and post-training sessions, which meant teachers rated themselves higher than a neutral/average point on the rating scale and were generally prepared to deal with the reading program.

Table 2. Means on the three TSE dimensions

\begin{tabular}{|c|c|c|c|c|c|}
\hline & Mean & $\mathrm{N}$ & $\begin{array}{c}\text { Std. } \\
\text { Deviation }\end{array}$ & $\begin{array}{c}\text { One sample } \\
\text { t-test } \\
(\text { Med.=3) }\end{array}$ & $\begin{array}{l}\text { Paired t } \\
\text { test }\end{array}$ \\
\hline Pre training: ability to find resources and judge quality & 4.43 & 7 & .535 & $9.84 * *$ & .42 \\
\hline Post training: ability to find resources and judge quality & 4.57 & 7 & .787 & $7.78 * *$ & \\
\hline Pre training: develop program & 4.43 & 7 & .535 & $7.31 * *$ & 1 \\
\hline Post training: develop program & 4.57 & 7 & .535 & $10.02 * *$ & \\
\hline Pre training: ability to motivate students & 4.43 & 7 & .535 & $10.31 * *$ & 0.55 \\
\hline Post training: ability to motivate students & 4.57 & 7 & .535 & $8.63 * *$ & \\
\hline
\end{tabular}

$* *$ Significant at $\mathrm{p}<0.01$

For the fourth analysis, we ran a repeated measure ANOVA using the treatment group. We used the pre-treatment and post-treatment attitude measures as the repeated dependent measures, and using the aggregate home literacy measure as a covariate. In this analysis, we were interested in determining the variance in the interaction effects, with the expectation that the post-treatment reading attitudes would increase in relation to an increase in home literacy. The interaction effects showed that this relation was not significant $(F(1,69)=2.30, p=0.13)$.

For the fifth analysis, we performed a mixed-design, i.e., split-plot ANOVA, which incorporated the repeated measure analysis and the between measure analysis, that is, the difference between those who enrolled in the reading program and those who did not. This comparison and measure was performed pre- and post-reading program, comparing those who enrolled with those who did not. The means of pre- and post-reading program are reported in Table 3.

Table 3. Means and standard deviations in control and experimental groups

\begin{tabular}{|c|c|c|c|c|}
\hline & Program & Mean & $\begin{array}{l}\text { Std. } \\
\text { tion }\end{array}$ & $\mathrm{N}$ \\
\hline \multirow{3}{*}{ Pre-treatment } & Non-Reading Program & 3.86 & 1.17 & 110 \\
\hline & Reading & 3.63 & 1.45 & 183 \\
\hline & Total & 3.71 & 1.36 & 293 \\
\hline \multirow{3}{*}{ Post-treatment } & Non-Reading Program & 4.04 & .79 & 110 \\
\hline & Reading & 4.13 & .72 & 183 \\
\hline & Total & 4.10 & .75 & 293 \\
\hline
\end{tabular}

The split-plot analysis shows within group difference between the two conditions - the reading and non-reading program $(\mathrm{F}(1,291)=16.14, \mathrm{p}<0.01)$. The mean difference could be contributed to more positive attitudes among students in the reading program. The most important analysis is the pre/post reading analysis interaction effects. Because of the significant differences between those students who participated in the reading program compared to those who did not participate, i.e., the control group, we wanted to determine whether the post- reading program results did, in fact, surpass those of the control group's post-reading program results. Figure 2 presents the marginal means of the pre and post-reading program measures and presents the measures in the control and treatment groups with respect to the pre and post-reading program. The interaction effect was near significant $F(1,291)=3.620$, $p=0.058$ even though the treatment group's interest in reading was lower than that of the control group (non-reading program). Post-reading program measures reflected a far higher increase in reading interest than that of students in the control group (see Figure 2). Given the size of the difference in the pre-reading program results between the control and treatment groups and the higher treatment mean for the post-reading program period, it can be concluded that the reading program participants may have had a substantial effect on their reading habits. 


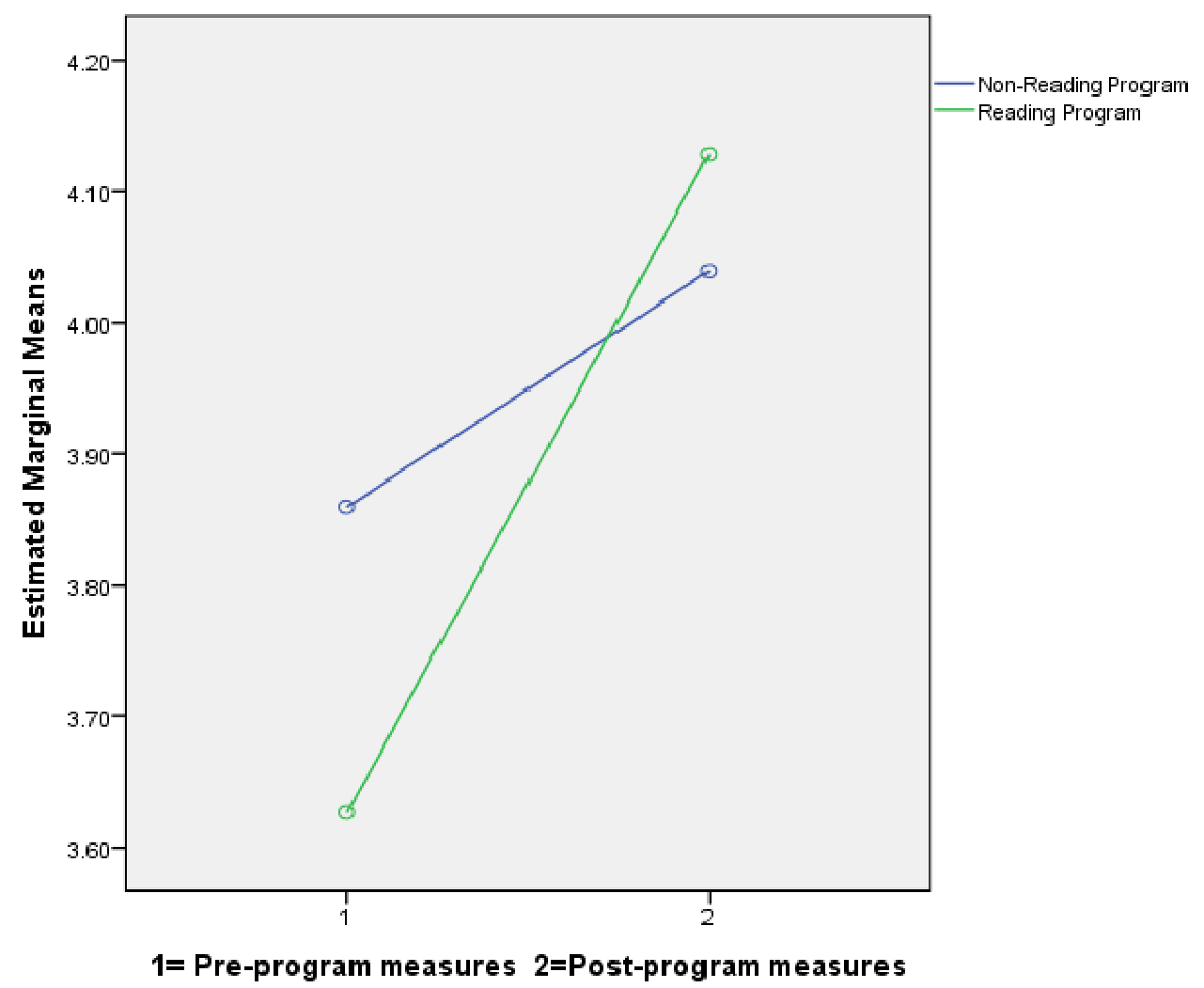

Figure 2. Pre and post reading program reading attitude measures

\section{Discussion}

We begin this section by summarizing the results of the study. We then consider how the findings might be interpreted in light of the success of the reading program.

The findings describe the evolution of reading as an extracurricular program as the teachers had a growing awareness of the development of the reading program and the classroom teaching strategies involved in the activity-based programs. Teachers who ran the reading program engaged the students in auditory and visual activities, and they motivated, encouraged, and monitored the students. However, the teachers did not focus on developing language or verbal skills, comprehension skills, word knowledge or auditory experiences as the reading program was designed for students to enjoy reading and improve their reading habits

Teacher self-efficacy was measured along three factors, those being: resources judged quality, developed a program and motivating students. The results showed that there was no significant differences between pre- and post-training period on the sense of self-efficacy. This finding suggests that training did not improve the teacher's sense of selfefficacy. However, the high rating indicated that teachers felt they were able to deliver programs effectively. Most teachers did not promote some of the skills outlined in teacher professional standards as well as curricular standards. These specific activities did not hinder teachers from other significant engagement to support students.

The significant finding of this study is that those students who participated in the extracurricular reading program had more positive reading attitudes than those who did not. What is highly significant in this research is that student interest in the treatment group surpassed those who did not participate in the reading program. Studies such as Plester and Wood (2009) suggest alternative reading discourses as being successful in attracting students to reading for pleasure. Others, such as Yelland (2005) and Jenkins (2008) have also challenged the traditional approaches to literacy, suggesting that non-formal extracurricular programs provide a sense of accomplishment. Even when removing the effects as the joint involvement of the parent and child in reading activities, such as the book literacy activity (Anderson \& Stokes, 1984; Purcell-Gates, 1996), those students who went through the extracurricular activity, their attitudes toward reading had improved over those students who did not go through the reading program.

Finally, the findings in this study suggest that organized extracurricular activities fared better, specifically with respect to those who participated in various activities during the reading program, thus suggesting that children who enjoyed the reading program had increased positive attitudes towards reading. This finding may also reflect the increased role of non-familial adults who establish closer relationship, these students will generally instill in students the normative, communal, leadership skills, interpersonal competences and other skills assumed to be critical to educational achievement (Mahoney, Cairns \& Farmer, 2003).

\section{Conclusion}

The project explored the attitudes towards reading in English (second language) and Arabic among grade fourth students in independent schools in Qatar. The knowledge generated from this research extended our understanding of 
the teacher professional development needed to address language skills of children and how implementing such programs in Arabic speaking countries might increase children's knowledge of Arabic and English. The outcome of this study suggested the development of an extracurricular reading for pleasure program. A blue print of this reading program was presented in this paper.

The main finding of this study suggests that those students who went through the extracurricular activity had increased student interest in reading even though the mean rating of the reading attitude of the treatment group was lower than the control group prior to enrollment in the reading program.

The establishment of a professional development model for reading for pleasure activities can be adapted to other grade levels and other content areas as well. It is obvious that specific professional development and unique proposed teaching activities must combine elements from both traditional workshop style and the alternative methods of professional development such as teacher reading activities if schools are to be successful in increasing student interest in reading.

Furthermore, the results from this project add to the literature on the development of extracurricular activities. The use of surveys and observations helped us to understand participants' feelings towards alternative informal literacy activities to support reading in Qatar as we attempt to establish and implement much needed literacy practices in a "predominantly oral culture."

In addition, using teacher experience to develop a reading program in Arabic and English supports the development of such modules that could then possibly be extended to different grade levels at the primary school. Furthermore, to incorporate such reading programs into strategies-based instruction, evaluation related to the project's research activities and professional development components is necessary.

\section{Recommendations and Limitations}

Teacher professional development activities did not foster self-efficacy, nor were there any observed teacher instructional strategies to foster critical reading skills, and problem-solving for greater language acquisition and adequate literacy opportunities for students, and whether these changes were in the students' attitudes towards reading or in the utilization of teacher professional development and skills. Future development of this study could explore the association between the length of the reading program implementation and reading comprehension scores, as well as the association between the number of years students have been exposed to extracurricular reading activities and reading comprehension scores. In addition, future research could explore the differences between the breadth and depth of these extracurricular programs. Further research must address this issue in the context of Qatar. We acknowledge that adequate time was not allotted for the extracurricular reading program specifically to activities related to reading instruction and reading comprehension.

Acknowledgement: This paper was made possible by a UREP award UREP $10-079-5-023$ from the Qatar National Research Fund (a member of The Qatar Foundation). The statements made herein are solely the responsibility of the author.

\section{References}

Abu-Rabia, S., \& Taha, H. (2006). "Reading in Arabic orthography: Characteristics, research findings, and assessment", In R.M. Joshi \& P.G. Aaron (eds.), Handbook of orthography and literacy, Mahwah, NJ, Lawrence Erlbaum Associates, pp. 321-338.

Anderson, A. B., \& Stokes, S. J. (1984). "Social and institutional influences on the development and practice of literacy”, In H. Goelman, A. Oberg, \& F. Smith (Eds.), Awakening to literacy, London: Heinemann, pp. 24-37.

Ary, D., Jacobs, L., Razavieh, A. (2002). Introduction to Research (6th Ed.), Belmont, CA, Wadsworth.

Ball, E. W., \& Blachman, B. A. (1991). "Does phoneme segmentation training in kindergarten make a difference in early word recognition and developmental spelling?", Reading Research Quarterly, Vol. 26, pp. 49-66.

Bandura, A. (1986). Social foundations of thought and action: A social cognitive theory, Englewood Cliffs, NJ, Prentice-Hall.

Birkerts, S. (1994). The Gutenberg elegies: The fate of reading in an electronic age, London, Faber and Faber.

Connor, C. M., Piasta, S. B., Fishman, B., Glasney, S., Schatschneider, C., Crowe, E., Underwood, P. \& Morrison, F., (2009). "Individualizing student instruction precisely: Effects of child $\times$ instruction interactions on first graders' literacy development", Child Development, Vol. 80, pp.77-100.

Cummins, J. (1979). "Linguistic interdependence and the educational development of bilingual children", Review of Educational Research, Vol. 49, pp. 222-251.

Durgunoglu, A. Y., Nagy, W. E., \&Hancin-Bhatt, B. J. (1993). "Cross-language transfer of phonological awareness", Journal of Educational Psychology, Vol. 85, pp. 453-465. 
Durlak, J. \& Weissberg, R. (2007). "The impact of after school programz that promote personal and social skills collaborative for academic, social and emotional learning (CASEL)", Available at www.casel.org/downloads/ASPFull.pdf (accessed 11 April 2011).

Ericsson, L. A. (1996). The role to excellence: The acquisition of expert performance in the arts, and sciences, sports, and games, Hillsdale, NJ, Lawrence Erlbaum.

Figueredo, L. (2006). "Using the known to chart the unknown: A review of first-language influence on the development of English-as-a-second-language spelling skill”, Reading and Writing, Vol. 19, pp. 873-905.

Fredricks, J. A., \& Eccles, J. S. (2005). "Developmental benefits of extracurricular involvement: Do peer characteristics mediate the link between activities and youth outcomes?" Journal of Youth and Adolescence, Vol. 6, pp. 507-520.

Fredricks, J. A., \& Eccles, J. S. (2006). "Is extracurricular participation associated with beneficial outcomes? Concurrent and longitudinal relations", Developmental Psychology, Vol. 42, pp. 698-713.

Fredricks, J. A., \& Eccles, J. S. (2010). "Breadth of extracurricular participation and adolescent adjustment among African-American and European- American youth", Journal of Research on Adolescence, Vol. 20, pp. 307-333.

Gorman, T. P. (1987). Pupils' attitudes to reading at Age 11 and 15, Windsor, NFER-NELSON.

Gough, P.B., \& Hillinger, M.L. (1980). "Learning to read: An unnatural act", Bulletin of the Orton Society, Vol. 30, pp.179-196.

Granger, R. C. \& Kane, T. (2004). "Improving quality of after-school programs", Education Week, 23, No. 23, Available at www.casel.org/downloads/ASP-Full.pdf (Accessed on 1 May 2011).

Howard, V. (2008). "Peer group influences on avid teen readers", New Review of Children's Literature and Librarianship, Vol. 14, pp. 103-119.

Guskey, T. R., \& Passaro, P. D. (1994). "Teacher efficacy: A study of construct dimensions", American Educational Research Journal, Vol. 31, pp. 627-643.

Jenkins, H. (2008). “Media literacy: Who needs it?”, In T. Willoughby and E. Wood (eds.), Children's learning in a digital world, Oxford, Blackwell, pp.16-39.

Juel, C. (1988). "Learning to read and write: A longitudinal study of children in first and second grade", Journal of Educational Psychology, Vol. 80, pp.437- 447.

Knight, S. L., \& Smith, R. G. (2004). "Development and use of a classroom observation instrument to investigate teaching for meaning in diverse classrooms", In H. C. Waxman, R. G. Tharp, \& R. S. Hilberg (Eds.), Observational research in U.S. classrooms: New approaches for understanding cultural and linguistic diversity, Cambridge, Cambridge University Press, pp. 97-119.

Mahoney, J. L., Cairns, B. D., \& Farmer, T. (2003). "Promoting interpersonal competence and educational success through extracurricular activity participation", Journal of Educational Psychology, Vol. 95, pp. 409-418.

Mahoney, J. L., Harris, A. L., \& Eccles, J. S. (2006). "Organized activity participation, positive youth development, and the overscheduling hypothesis", Society for Research in Child Development: Social Policy Report, Vol. 20, pp.1-30.

Merriam, S. B., (1998). Qualitative research and case study applications in education, San Francisco, CA, Jossey Bass.

McCardle, P., \& Chhabra, V. (Eds.) (2004). The voice of evidence in reading research. Baltimore, MD, Paul H. Brookes Publishing Co.

Metsapelto, R. L. \& Pulkkinen, L. (2012). "Socioemotional behavior and school achievement in relation to extracurricular activity participation in middle childhood", Scandinavian Journal of Educational Research, Vol. 56, pp. $167-182$.

Murad, C.R., \& Topping, K. (2000). "Parents as reading tutors for fist grader in Brazil", Social Psychology International, Vol. 21, pp. 152-172.

Plester, B. \& Wood, C. (2009). "Exploring relationships between traditional and new media literacies: British preteen texters at school", Journal of Computer-Mediated Communication, Vol. 14, pp. 1108-1129.

Purcell-Gates, V. (1996). "Stories, coupons, and the TV guide: Relationships between home literacy experiences and emergent literacy knowledge", Reading Research Quarterly, Vol. 31, pp. 406-428.

Rayner, K., Foorman, B. R., Perfetti, C. A., Pesetsky, D., \& Seidenberg, M. S. (2001). "How psychological science informs the teaching of reading", Psychological Science in the Public Interest, Vol. 2, pp. 31-74.

Ross, S. M., \& Smith, L. J. (1996). Classroom observation measure observer's manual Memphis, TN, University of Memphis, Center for Research in Educational Policy.

Ross, S. M., Smith, L. J., Lohr, L., \& McNelis, M. M. (1994). "Math and reading instruction in tracked first-grade classes", The Elementary School Journal, Vol. 95, pp. 105-109.

Ross, S. M., Troutman, A., Horgan, P., Maxwell, S., Laitinen, R., \& Lowther, D. (1997). "The success of schools in implementing eight restructuring designs: A synthesis of first-year evaluation outcomes", School Effectiveness and School Improvement, Vol. 8, pp. 95-124. 
Ryan, A. M. (2011). "Peer relationships and academic adjustment during early adolescence”, The Journal of Early Adolescence, Vol. 31, pp. 5-12.

Seymour, P.H.K. (2006). "Theoretical framework for beginning reading in different orthographies", In R.M. Joshi \& P.G. Aaron (eds.), Handbook of orthography and literacy, Mahwah, NJ, Lawrence Erlbaum Associates, pp. 441-462.

Topping, K. J., (2000). Thinking reading and writing: A practical guide to paired learning with peers, parents and volunteers. London and New York, Cassell.

Towey, C. A., (2001). "Flow: "The benefits of pleasure reading and tapping readers' interests."”, In B. Katz (Ed.), Readers, reading, and librarians, New York, Haworth Press, pp. 131-140.

Treiman, R. (2000). “The foundations of literacy”, Current Directions in Psychological Science, Vol. 9, pp. 89-92.

Tschannen-Moran, M., \& Woolfolk Hoy, A. (2001). "Teacher efficacy: Capturing an elusive construct", Teaching and Teacher Education, Vol. 17, pp. 783-805.

Waxman, H. C., Hilberg, R. S., \& Tharp, R. G. (2004). "Future directions for classroom observation research", In H. C. Waxman, R. G. Tharp, \& R. S. Hilberg (Eds.), Observational research in U. S. classrooms: New approaches for understanding cultural and linguistic diversity, Cambridge, United Kingdom, Cambridge University Press, pp. 266277.

Whitehurst, G., \&Lonigan, C. (2001). "Emergent literacy: Development from prereaders to readers", In S. B. Neuman \& D. K. Dickinson (Eds.), Handbook of early literacy research New York, Guilford, pp. 11-29.

Yelland, N. (Ed.) (2005). Critical issues in early childhood education, Maidenhead, Open University Press.

Wolfendale, S. W., \& Topping, K. J. (eds.) (1996). Family involvement in literacy: Effective partnerships in education, London and New York, Cassel. 